\title{
Nutritional regulation of muscle protein synthesis with resistance exercise: strategies to enhance anabolism
}

Tyler A Churchward-Venne, Nicholas A Burd and Stuart M Phillips*

\begin{abstract}
Provision of dietary amino acids increases skeletal muscle protein synthesis (MPS), an effect that is enhanced by prior resistance exercise. As a fundamentally necessary process in the enhancement of muscle mass, strategies to enhance rates of MPS would be beneficial in the development of interventions aimed at increasing skeletal muscle mass particularly when combined with chronic resistance exercise. The purpose of this review article is to provide an update on current findings regarding the nutritional regulation of MPS and highlight nutrition based strategies that may serve to maximize skeletal muscle protein anabolism with resistance exercise. Such factors include timing of protein intake, dietary protein type, the role of leucine as a key anabolic amino acid, and the impact of other macronutrients (i.e. carbohydrate) on the regulation of MPS after resistance exercise. We contend that nutritional strategies that serve to maximally stimulate MPS may be useful in the development of nutrition and exercise based interventions aimed at enhancing skeletal muscle mass which may be of interest to elderly populations and to athletes.
\end{abstract}

Keywords: Nutrition, Muscle, Anabolic intramuscular signaling, Hypertrophy

\section{Introduction}

The synergistic effects of amino acid provision and resistance exercise on skeletal muscle protein synthesis rates (MPS) are now well described (for reviews see: $[1,2])$. Consuming dietary amino acids after resistance exercise stimulates an increase in MPS and is necessary to shift net protein balance (defined as MPS minus muscle protein breakdown (MPB)) from negative (net protein loss) to positive (net protein gain) [3]. In healthy individuals, feeding-induced changes in MPS are $\sim 3-5$ times greater over the course of any given day than measurable changes in MPB, demonstrating that MPS is highly responsive, regulated, and represents the primary driver of changes in muscle net protein balance. As such, it would follow that for chronic elevations in net muscle protein balance to result in gains in muscle mass, changes in MPS are highly relevant. We do not contend that MPB is a trivial biological process; MPB assists in maintenance of intracellular amino acid levels, and likely plays a role in maintaining muscle protein quality by

* Correspondence: phillis@mcmaster.ca

Department of Kinesiology, McMaster University, Hamilton, ON, Canada removing damaged proteins and allowing their constituent amino acids to be used for the synthesis of new functional muscle proteins. Consequently, we propose that nutritional interventions that enhance MPS may be of great scientific and clinical interest as a strategy to promote positive muscle protein balance and eventual muscle protein accrual. Further, these interventions may be of interest to athletes concerned with enhancing the adaptive response of skeletal muscle to chronic exercise training. Current research has demonstrated that factors such as the dose of dietary protein/essential amino acids (EAA) ingested $[4,5]$, protein food source (i.e. whey, soy, micellar casein) [6-9], and timing of protein/EAA intake [9-11] impact the magnitude (and possibly the duration) of MPS in response to feeding and resistance exercise. Other research has focused on the ability to enhance MPS by providing increased amounts of leucine [12-14] or arginine [15] within an amino acid containing solution. Lastly, the influence of consuming mixed macronutrients on muscle protein metabolism [16-20] has also received some attention. The purpose of this review is to discuss the nutritional regulation of human MPS and 
provide an update on nutritional strategies that may serve to maximize MPS with feeding and resistance exercise.

\section{Redefining the 'window of anabolic potential' after resistance exercise}

Although the amino acid mediated increase in MPS is transient, lasting only a few hours at most [21-23], the contractile activity associated with intense resistance exercise results in increased rates of MPS that are sustained for $\sim 48 \mathrm{~h}$ in the fasted state in young participants [24]. It is now unequivocal that immediate post-exercise amino acid provision is an effective nutrition based strategy to enhance MPS above rates observed with exercise alone $[3,5,25]$. The importance of early post-exercise protein ingestion relates to the fact that exercisemediated increases in rates of MPS are greatest immediately after exercise ( $100-150 \%$ above basal rates) [2], and thus the synergistic effects of exercise and feeding on MPS are likely greatest during this time-period. However, since resistance exercise increases MPS for up to $\sim 48 \mathrm{~h}$ [24] consumption of dietary amino acids $24-48 \mathrm{~h}$ post-exercise recovery would also likely convey the same synergistic effects on MPS as those that are observed when amino acids are provided immediately after resistance exercise $[7,8,25,26]$. As shown in Figure 1, the synergistic enhancement of pre-existing resistance exerciseinduced elevations in MPS by protein provision is greatest immediately post-exercise and wanes over time, but may still be present up to $48 \mathrm{~h}$ later. We have recently shown that feeding $15 \mathrm{~g}$ of whey protein, a less than optimally effective dose of protein for maximizing MPS [5], $\sim 24 \mathrm{~h}$ after acute resistance exercise results in a greater stimulation of myofibrillar (contractile proteins of skeletal muscle) protein synthesis than the same dose

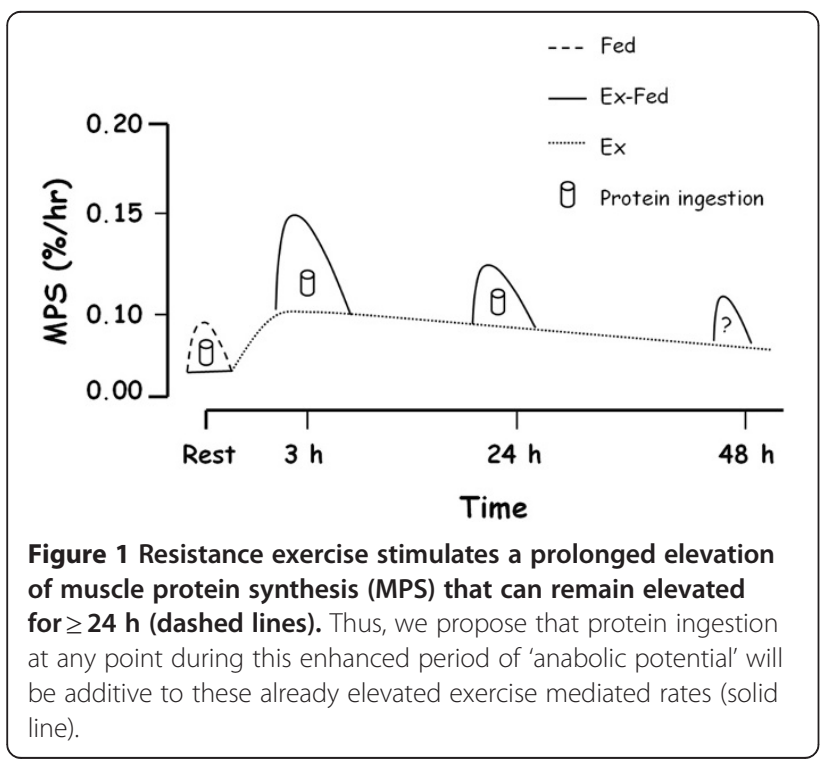

provided at rest [27] (Figure 2). However, the effect of enhanced sensitivity to protein ingestion induced by prior resistance exercise performed $24 \mathrm{~h}$ earlier was independent of the amount of weight lifted. Specifically, resistance exercise was performed at a relatively high load (90FAIL) or low load (30FAIL), but both regimens were performed to volitional fatigue. Thus, irrespective of exercise load, the ultimate result was eventual similar increases in muscle fibre recruitment [28]. Future research should examine if there are age-related differences in the ability of resistance exercise to convey an enhanced sensitivity of MPS to protein ingestion when consumed $\sim 24 \mathrm{~h}$ after exercise, and whether this effect is influenced by the type of protein consumed as these results would be relevant to increasing our understanding of the factors involved in age-related muscle loss.

Overnight nutrient provision may also represent an effective nutritional strategy to stimulate MPS, and thus increase the 'window of anabolic opportunity' by promoting a greater muscle net protein balance over the course of $24 \mathrm{~h}$. Previous research has shown that overnight MPS rates are quite low [29], however both intragastric protein provision during sleep [30], and oral protein ingestion after resistance exercise immediately before bed [31] are followed by normal protein digestion and absorption kinetics and an overnight stimulation of MPS. Therefore, we contend that properly planned

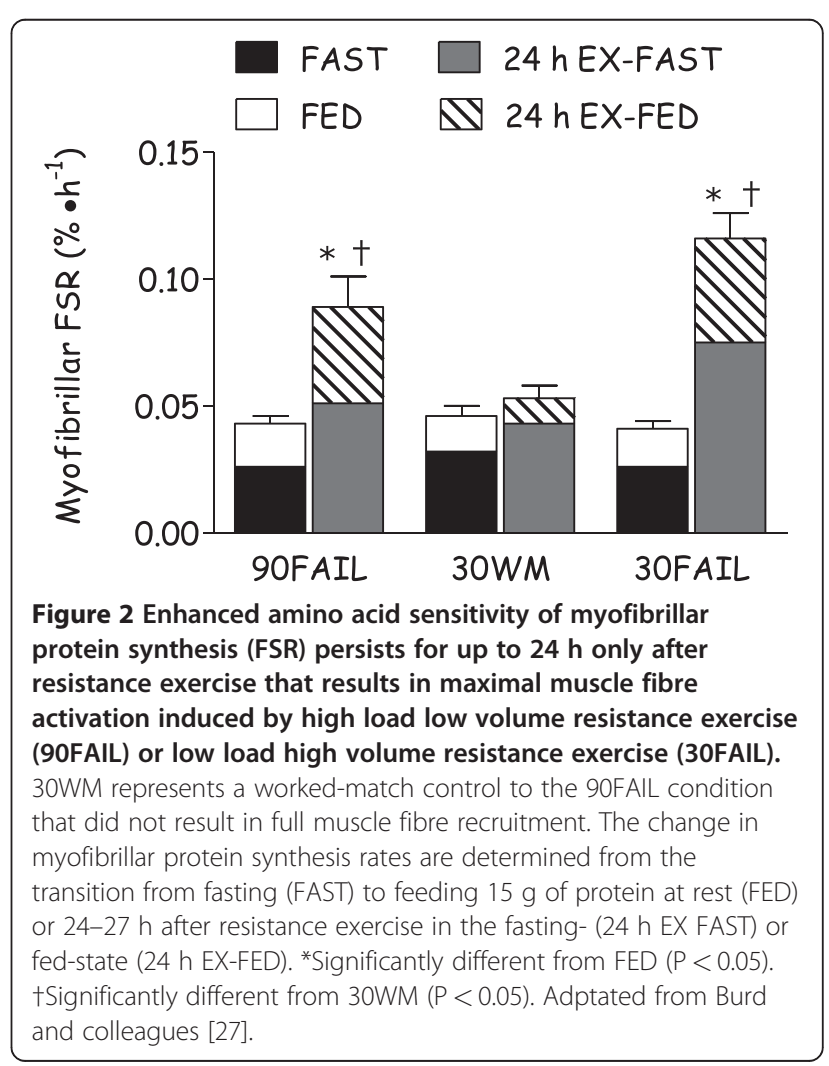


protein/EAA provision, not only immediately after, but up to $\sim 24 \mathrm{~h}$ following exercise should be carefully considered as a dietary strategy to maximally stimulate exercise-induced rates of MPS.

\section{Mechanisms underpinning the enhanced sensitivity of skeletal muscle after exercise}

Dietary amino acids and insulin are major nutrientregulated effectors of MPS and MPB and recent work has shed light on the molecular pathways involved in regulating the amino acid and contraction-induced increase in MPS. A comprehensive review of the molecular regulation of MPS in response to nutrition and exercise is beyond the scope of this article but can be found elsewhere [32]. The protein kinase mTORC1 serves as a critical point of integration from a wide range of signals that promote MPS, including dietary amino acids [33] and muscle contraction [34]. Specifically, mTORC1 regulates MPS by phosphorylation of downstream protein effectors such as p70S6k and 4E-BP1 that are involved in translation initiation of MPS. Further, blocking mTOR activity with the drug rapamycin blocks both the contraction [34], and EAA [33] mediated increase in human MPS, demonstrating the essentiality of this kinase in the regulation of MPS. To date, several studies have demonstrated that amino acid provision after resistance exercise and the subsequent increase in MPS are associated with enhanced phosphorylation of components of the mTOR signaling cascade above levels that are observed following exercise without nutrients [26,35-37]. However, dissociation between direct measures of rates of MPS and the extent of muscle anabolic signaling molecule phosphorylation has been reported previously $[13,38]$. Further, exactly how amino acids are able to activate mTORC1 to increase MPS is not understood, although MAP4K3 [39], vacuolar sorting protein 34 (Vps34) [40,41], and Rag GTPases [42] are signaling proteins that are candidate amino acid 'sensors' capable of responding to changes in amino acid concentration with subsequent activation of mTORC1. In addition, the mRNA expression of select skeletal muscle amino acid transporters such as LAT1 (SLC7A5), SNAT2 (SLC38A2), CD98 (SLC3A2), and PAT1 (SLC36A1) has been reported to be increased following EAA ingestion [43] and resistance exercise [44] in human skeletal muscle. These transporters may play an important role in the regulation of human muscle protein metabolism based on their ability to transport amino acids across the cell membrane, and relay signals to downstream targets thought to regulate MPS [45]. An increase in the protein levels of some of these amino acid transporters has also been observed following EAA ingestion [43] and resistance exercise [44], however it is currently unclear whether increases in mRNA and protein expression of these transporters are associated with enhanced amino acid transport capacity. Clearly, further research is needed to define the functional and physiological significance of these transporters in the nutrition and exercise mediated regulation of MPS.

\section{Optimizing MPS: the role of protein source}

The ingestion of dietary proteins including whey $[5-8,21,27,46,47]$, egg albumin [5], soy [7,8], casein $[6,8]$, and beef $[48,49]$ are all able to stimulate MPS. However, dietary proteins from different sources differ in their capacity to stimulate MPS both at rest [6-8] and following resistance exercise $[7,8]$. For example, work from our lab has shown that whey protein [8] and bovine milk [7] promote greater increases in MPS after acute resistance exercise than does consumption of an equivalent amount of plant-based soy protein despite the fact that these protein sources have protein digestibility-corrected amino acid scores (PDCAAS) above 1.0. The limitations of the PDCAAS scoring system and the artificial truncation at 1.0, when some proteins have a PDCAAS of $>1.0$, has been discussed in our previous review [50]. The mechanisms responsible for these differences are not entirely clear but may relate to important differences in the amino acid profile and/or amino acid availability due to differences in the digestion/absorption kinetics of the proteins. Whey protein is acid soluble and is associated with a very rapid, large, but transient increase in postprandial amino acid availability [6,51], while casein coagulates and precipitates when exposed to stomach acid and the resultant dairy curd is slowly released from the stomach resulting in a much more moderate but sustained rise in plasma amino acids [6,51]. Our lab has recently compared the effects of whey protein isolate to micellar casein on rates of MPS in elderly men [52]. Consistent with our previous findings in young subjects [8] we reported greater increases in blood leucine concentration and increases in both rested and post-exercise MPS after ingestion of $20 \mathrm{~g}$ of whey protein isolate than ingestion of micellar casein. This data corroborates our previous work showing that a rapid rate of amino acid appearance in the blood after feeding enhances MPS and anabolic cell-signaling after resistance exercise more than a slow rate of amino acid appearance [53], supporting the notion that protein digestion and absorption rate represents an important factor in the nutritional regulation of MPS in humans $[8,47,51,52,54,55]$. Our data on MPS are dissimilar, in some regards, to results obtained from studies of wholebody protein turnover $[51,54,55]$, likely because skeletal muscle accounts for only $\sim 30 \%$ of whole body protein synthesis [56] and turns over at a rate that is significantly less ( 20-fold) than both splanchnic [57] and plasma proteins [58]. Interestingly, recent research suggests that the form of food (i.e. liquid vs. solid) may be an important 
factor regulating postprandial plasma amino acid availability [59]. For example, Conley and colleagues [59] showed greater increases in plasma amino acids that were more sustained following beverage administration as compared to the same supplement (i.e. energy and macronutrient matched) provided in solid food-form. These findings are interesting in light of the fact that the postprandial rise in plasma EAA [60] and/or leucine [61,62] appears to be key regulator of the postprandial rise in MPS, but more research is needed to determine the physiological relevance of food form as it pertains to the regulation of MPS.

\section{Leucine as a nutrient signal in skeletal muscle}

Of the amino acids, the EAA are primarily responsible for stimulating MPS [63,64], whereas non-essential amino acids appear ineffective in this regard [65]. The branched-chain amino acid (BCAA) leucine appears unique among the EAA as a key regulator of translation initiation of MPS [66,67]. For example, leucine, but not isoleucine or valine can stimulate an increase in MPS through activation of the mTOR-p70S6k pathway in animals $[66,68]$. Work in cell culture utilizing C2C12 cells has demonstrated that leucine is the most potent among the EAA in its ability to increase the phosphorylation status of p70S6k, and the only EAA capable of increasing the phosphorylation status of mTOR and 4E-BP1 [69]. Taking these data into account, recent research has focused on utilizing leucine as part of a nutritional intervention to modulate MPS and/or muscle mass in humans. Tipton and colleagues [12] examined the effect of free leucine $(3.4 \mathrm{~g})$ added to whey protein $(16.6 \mathrm{~g})$ on rates of MPS after acute resistance exercise and reported no further increase in MPS with the addition of free leucine compared to that previously reported for $20 \mathrm{~g}$ whey protein. However, these data are not surprising in light of work from our group [5] and others [4] in which the dose-response relationship between protein/EAA ingestion and MPS was examined. Moore and colleagues [5] reported that MPS was maximally stimulated in young men with $20 \mathrm{~g}$ of high-quality protein after resistance exercise, with $40 \mathrm{~g}$ of protein resulting not in increased MPS above that observed with $20 \mathrm{~g}$, but simply elevated levels of amino acid oxidation. Thus, ingestion of leucine in amounts greater than that found in a saturating dose (20-25 g whey protein containing 2.5-3.0 g leucine) of high quality protein, is unlikely to further stimulate an increase in the magnitude or duration of MPS. However, these data are taken from young healthy men weighing $\sim 86 \mathrm{~kg}$ and the maximally effective dose of protein may be quite different in, for example, a $\sim 50 \mathrm{~kg}$ female gymnast or a $120 \mathrm{~kg}$ bodybuilder. The elderly also represent a population that may require greater amounts of dietary protein and/or leucine to mount a robust increase in MPS in response to feeding [70,71]. Future research is needed to define the amount of leucine required to stimulate MPS in both young and elderly adults and to clearly establish the role of other EAA in the regulation of MPS with feeding and resistance exercise.

\section{Post-exercise nutrition for the elderly}

Defining nutritional interventions that maximally stimulate rates of MPS are of interest in the development of therapeutic strategies designed combat age-related muscle loss (sarcopenia). The cause of sarcopenia is likely multi-facted [72], however some evidence suggests that that the elderly are 'resistant' to the anabolic effects of amino acids [4,73] and resistance exercise [74], and to the anti-proteolytic effects of insulin [75]. For example, Kumar and colleagues [74] reported an age-related blunting of the MPS response in the post-absorptive state following acute resistance exercise performed over a range of intensities (20-90\% 1RM) when measured over 1-2 h post-exercise recovery. However, since freeliving individuals typically eat after resistance exercise, it can only be speculated whether the same blunted MPS response between young and old would have been observed in the fed-state.

Despite the diminished response to amino acid provision and exercise in the elderly, it appears that the additive effects of feeding and resistance exercise on rates of MPS are preserved in this population, with several studies showing that combined feeding and exercise results in greater increases in MPS than feeding alone $[48,52,76]$. Our lab has recently examined the dose-response relationship between whey protein ingestion and myofibrillar protein synthesis under both rested and post-resistance exercise conditions in the elderly [76]. Contrary to young participants in whom MPS is maximally stimulated after resistance exercise with $\sim 20 \mathrm{~g}$ of protein, $40 \mathrm{~g}$ of protein increased rates of MPS in the elderly more than $20 \mathrm{~g}$ when consumed after resistance exercise [76], suggesting that the elderly may benefit from a greater amount of amino acids and/or leucine after resistance exercise to maximize myofibrillar protein synthesis. In support of the elderly responding to greater amounts of leucine, Katsanos and colleagues (2006) reported that a $6.7 \mathrm{~g}$ mixture of EAA containing 26\% leucine was unable to promote an increase MPS above basal levels in the elderly; however, when the leucine content of the same EAA mixture was increased to $41 \%$, MPS was stimulated above basal to the same extent as that observed in young subjects [70]. These findings suggest that amino acid composition, and not simply total EAA is of key importance in determining the postprandial response of MPS in elderly muscle. However, the efficacy of free leucine supplementation with meal feeding as a strategy to augment muscle mass in the elderly is not currently supported. Verhoeven and colleagues 
(2009) examined the efficacy of long-term leucine supplementation on skeletal muscle mass in elderly subjects and reported that supplemental leucine $(7.5 \mathrm{~g}$ per day with meals) for a 12-week period did not increase skeletal muscle mass or strength when compared to an energymatched placebo [77]. However, this was only in subjects who were consuming standard meals and meal-induced gains in lean mass from feeding alone, without resistance exercise are likely to be small, especially over a period of 12 weeks. Further, the leucine supplementation was associated with declines in circulating valine and isoleucine which could have become limiting for the stimulation of MPS [77]. Studies in animals have shown that leucine provision leads to a decline in circulating EAA and reduces the duration of the amino acid mediated increase in MPS [78]; however, when this decrease is prevented and basal amino acid concentrations are maintained, the response of MPS to amino acid provision lasts $\sim 2$ hours [79]. Overall, additional dietary leucine, which may be obtained from high quality proteins and not necessarily in crystalline form, may be of some benefit to the elderly from the perspective of increasing MPS [70,71]. More research is needed to examine the effect of leucine-enriched amino acid provision in the early time period after resistance exercise on MPS and gains in lean mass following more long-term training.

Recently, Smith and colleagues (2011a, 2011b) have examined the role of supplemental ( $4 \mathrm{~g}$ day for 8 weeks) omega 3 polyunsaturated fatty acids on rates of MPS and the activation of signaling proteins within the mTOR-p70S6k pathway in both young and middle aged [80], and elderly subjects [81]. In all age groups examined, supplementation with omega 3 fatty acids significantly increased the magnitude of the amino acid/insulin induced stimulation of MPS and phosphorylation of mTOR [80,81]. Although the mechanisms are currently unknown, these results suggest that omega 3 polyunsaturated fatty acids possess anabolic properties via their ability to enhance the sensitivity of skeletal muscle to amino acids and insulin, even in young healthy individuals $[80,81]$. Recently it has been shown that supplemental fish oil ( $2 \mathrm{~g} /$ day $)$ is also able to enhance the adaptive response to chronic resistance exercise training by promoting increases in muscle strength in elderly women [82]. Future research should examine the role of supplemental omega 3 polyunsaturated fatty acids on lean muscle mass accrual following a period of chronic resistance exercise training in both the young and elderly.

\section{Role of carbohydrate and insulin in the regulation of muscle protein metabolism}

Consumption of a typical mixed meal is generally associated with the ingestion of not only dietary proteins and amino acids, but also carbohydrates and lipids. While almost nothing is known about the impact of lipidprotein co-ingestion on direct measures of MPS with feeding and resistance exercise, Elliot and colleagues [83] reported that threonine and phenylalanine uptake (indicative of an anabolic response) was greater after ingestion of whole milk $(8.2 \mathrm{~g}$ fat, $8.0 \mathrm{~g}$ protein, 11.4 carbohydrate: total $627 \mathrm{kcal}$ ) as compared to fat free milk or isocaloric control conditions that were devoid of fat. The reason for the greater anabolism after whole milk ingestion is not entirely clear; however, it may relate to the greater muscle perfusion, at least in that study. Previous studies have investigated the role of carbohydrate $(\mathrm{CHO})$ in the regulation of human muscle protein metabolism [16-19,84]. Intake of $\mathrm{CHO}$ is associated with increased levels of circulating insulin, which has a strong inhibitory effect on MPB $[38,85,86]$, and thus is able to improve net protein balance [16-19,84]. However, in the absence of amino acid intake, $\mathrm{CHO}$ intake does not result in a positive net protein balance $[19,84]$. Our lab has recently examined the effect of carbohydrate-protein co-ingestion as compared to protein intake alone on rates of MPS and MPB after acute resistance exercise in young men [17]. Subjects consumed $25 \mathrm{~g}$ of whey protein or $25 \mathrm{~g}$ of whey protein with $50 \mathrm{~g}$ of added $\mathrm{CHO}$ as maltodextrin. Area under the plasma insulin curve was $\sim 5$-fold higher following protein-carbohydrate co-ingestion, however measures of limb blood flow, MPS, and MPB at rest and after resistance exercise were not different as compared to protein alone [17]. Therefore, when protein intake is of sufficient quantity to maximize MPS (see [5]), the resulting hyperaminoacidemia/hyperinsulinemia is sufficient to not only maximize MPS, but also fully inhibit MPB. These findings corroborate earlier work by Greenhaff and colleagues (2008) who demonstrated that low concentrations ( $5 \mathrm{mU} / \mathrm{L})$ of insulin are required to mediate a maximal amino acid induced stimulation of leg protein synthesis, and that increasing plasma insulin up to $30 \mathrm{mU} / \mathrm{L}$ was required to reduce leg protein breakdown by over $50 \%$ and increase net protein balance, but concentrations above this were not further inhibitory for protein breakdown [38]. It is important to note that although $\mathrm{CHO}$ may not be fundamentally important in altering net protein balance after resistance exercise when adequate protein is provided, muscle glycogen is reduced following resistance exercise $[87,88]$ and $\mathrm{CHO}$ has an important role in muscle glycogen resynthesis and is therefore useful to enhance recovery from training [89].

\section{Conclusions}

Nutritional interventions designed to maximally stimulate MPS may be useful for those individuals concerned with enhancing skeletal muscle protein accretion, particularly when they are combined with a program of 
chronic resistance exercise. Factors including protein/ EAA dose, protein source, timing of protein ingestion, and amino acid composition appear to impact the magnitude, and possibly duration, of postprandial MPS. Therefore, in terms of current recommendations it appears that consumption of $\sim 20-25 \mathrm{~g}$ (corresponding to $\sim 8-10$ g EAA) [5] of a rapidly absorbed protein $[6,8,53]$ may serve to maximally stimulate MPS after resistance exercise in young healthy individuals. Ideal candidates to fulfill such criteria appear to be whey $[6,8]$ or bovine milk [7]. Whether these recommendations hold for individuals outside of $\sim 80-90 \mathrm{~kg}$ is unknown and future research is warranted to address this question.

For the elderly, consumption of high quality leucinerich proteins, such as whey, may be of primary importance to maximize MPS [70,71] although addition of free leucine to meals does not appear to be an effective strategy to enhance muscle mass or strength, at least when measured over 12 weeks [77]. We propose that there is, at least in young individuals, an extended 'window of anabolic opportunity' beyond the immediate post-exercise period that persists for at least $24 \mathrm{~h}$, which may result from muscle fibre recruitment dependent enhanced sensitivity of skeletal muscle to amino acid provision. Although amino acids appear to be the primary nutrient effectors of MPS and can independently enhance muscle protein accrual, their effect on MPS, and ultimately muscle growth will be enhanced by chronic resistance exercise.

\section{Abbreviations}

CHO: Carbohydrate; EAA: Essential amino acid; MPB: Muscle protein breakdown; MPS: Muscle protein synthesis.

\section{Competing interests}

The authors declare that they have no competing interests.

\section{Acknowledgments}

We thank Daniel West and Cameron Mitchell for helpful discussions and feedback on the manuscript.

\section{Funding}

Funding for this project was provided by the Natural Science and Engineering Research council of Canada (NSERC) and by the Canadian Institute of Health Research (CIHR) grants to SMP and an NSERC postgraduate scholarship to TACV.

\section{Authors' contributions}

TACV, NAB, and SMP wrote and edited the manuscript. All authors read and approved the final manuscript.

Received: 9 February 2012 Accepted: 17 May 2012

Published: 17 May 2012

\section{References}

1. Burd NA, Tang JE, Moore DR, Phillips SM: Exercise training and protein metabolism: influences of contraction, protein intake, and sex-based differences. J Appl Physiol 2009, 106:1692-1701.

2. Kumar V, Atherton P, Smith K, Rennie MJ: Human muscle protein synthesis and breakdown during and after exercise. J Appl Physiol 2009, 106: 2026-2039.
3. Biolo G, Tipton KD, Klein S, Wolfe RR: An abundant supply of amino acids enhances the metabolic effect of exercise on muscle protein. Am J Physiol 1997, 273:E122-E129.

4. Cuthbertson D, Smith K, Babraj J, Leese G, Waddell T, Atherton P, Wackerhage H, Taylor PM, Rennie MJ: Anabolic signaling deficits underlie amino acid resistance of wasting, aging muscle. The FASEB journal: official publication of the Federation of American Societies for Experimental Biology 2005, 19:422-424.

5. Moore DR, Robinson MJ, Fry JL, Tang JE, Glover El, Wilkinson SB, Prior T, Tarnopolsky MA, Phillips SM: Ingested protein dose response of muscle and albumin protein synthesis after resistance exercise in young men. Am J Clin Nutr 2009, 89:161-168.

6. Pennings B, Boirie $Y$, Senden JM, Gijsen AP, Kuipers H, van Loon LJ: Whey protein stimulates postprandial muscle protein accretion more effectively than do casein and casein hydrolysate in older men. Am J Clin Nutr 2011, 93:997-1005.

7. Wilkinson SB, Tarnopolsky MA, Macdonald MJ, Macdonald JR, Armstrong D, Phillips SM: Consumption of fluid skim milk promotes greater muscle protein accretion after resistance exercise than does consumption of an isonitrogenous and isoenergetic soy-protein beverage. Am J Clin Nutr 2007, 85:1031-1040.

8. Tang JE, Moore DR, Kujbida GW, Tarnopolsky MA, Phillips SM: Ingestion of whey hydrolysate, casein, or soy protein isolate: effects on mixed muscle protein synthesis at rest and following resistance exercise in young men. J Appl Physiol 2009, 107:987-992.

9. Hartman JW, Tang JE, Wilkinson SB, Tarnopolsky MA, Lawrence RL, Fullerton AV, Phillips SM: Consumption of fat-free fluid milk after resistance exercise promotes greater lean mass accretion than does consumption of soy or carbohydrate in young, novice, male weightlifters. Am J Clin Nutr 2007, 86:373-381.

10. Tipton KD, Rasmussen BB, Miller SL, Wolf SE, Owens-Stovall SK, Petrini BE, Wolfe RR: Timing of amino acid-carbohydrate ingestion alters anabolic response of muscle to resistance exercise. Am J Physiol Endocrinol Metab 2001, 281:E197-E206.

11. Fujita S, Dreyer HC, Drummond MJ, Glynn EL, Volpi E, Rasmussen BB: Essential amino acid and carbohydrate ingestion before resistance exercise does not enhance postexercise muscle protein synthesis. J Appl Physiol 2009, 106:1730-1739.

12. Tipton KD, Elliott TA, Ferrando AA, Aarsland AA, Wolfe RR: Stimulation of muscle anabolism by resistance exercise and ingestion of leucine plus protein. Applied physiology, nutrition, and metabolism = Physiologie appliquee, nutrition et metabolisme 2009, 34:151-161.

13. Glynn EL, Fry CS, Drummond MJ, Timmerman KL, Dhanani S, Volpi E, Rasmussen BB: Excess leucine intake enhances muscle anabolic signaling but not net protein anabolism in young men and women. J Nutr 2010, 140:1970-1976.

14. Koopman R, Verdijk LB, Beelen M, Gorselink M, Kruseman AN, Wagenmakers AJ, Kuipers $\mathrm{H}$, van Loon LJ: Co-ingestion of leucine with protein does not further augment post-exercise muscle protein synthesis rates in elderly men. Br J Nutr 2008, 99:571-580.

15. Tang JE, Lysecki PJ, Manolakos JJ, MacDonald MJ, Tarnopolsky MA, Phillips SM: Bolus arginine supplementation affects neither muscle blood flow nor muscle protein synthesis in young men at rest or after resistance exercise. J Nutr 2011, 141:195-200.

16. Glynn EL, Fry CS, Drummond MJ, Dreyer HC, Dhanani S, Volpi E, Rasmussen BB: Muscle protein breakdown has a minor role in the protein anabolic response to essential amino acid and carbohydrate intake following resistance exercise. Am J Physiol Regul Integr Comp Physiol 2010, 299: R533-R540.

17. Staples AW, Burd NA, West DW, Currie KD, Atherton PJ, Moore DR, Rennie MJ, Macdonald MJ, Baker SK, Phillips SM: Carbohydrate does not augment exercise-induced protein accretion versus protein alone. Medicine and science in sports and exercise 2011, 43:1154-1161.

18. Roy BD, Tarnopolsky MA, MacDougall JD, Fowles J, Yarasheski KE: Effect of glucose supplement timing on protein metabolism after resistance training. J Appl Physiol 1997, 82:1882-1888.

19. Borsheim E, Cree MG, Tipton KD, Elliott TA, Aarsland A, Wolfe RR: Effect of carbohydrate intake on net muscle protein synthesis during recovery from resistance exercise. J Appl Physiol 2004, 96:674-678.

20. Koopman R, Beelen M, Stellingwerff T, Pennings B, Saris WH, Kies AK, Kuipers $\mathrm{H}$, van Loon LJ: Coingestion of carbohydrate with protein does 
not further augment postexercise muscle protein synthesis. Am J Physiol Endocrinol Metab 2007, 293:E833-E842.

21. Moore DR, Tang JE, Burd NA, Rerecich T, Tarnopolsky MA, Phillips SM: Differential stimulation of myofibrillar and sarcoplasmic protein synthesis with protein ingestion at rest and after resistance exercise. J Physiol 2009, 587:897-904.

22. Atherton PJ, Etheridge T, Watt PW, Wilkinson D, Selby A, Rankin D, Smith K, Rennie MJ: Muscle full effect after oral protein: time-dependent concordance and discordance between human muscle protein synthesis and mTORC1 signaling. Am J Clin Nutr 2010, 92:1080-1088.

23. Bohe J, Low JF, Wolfe RR, Rennie MJ: Latency and duration of stimulation of human muscle protein synthesis during continuous infusion of amino acids. J Physio/ 2001, 532:575-579.

24. Phillips SM, Tipton KD, Aarsland A, Wolf SE, Wolfe RR: Mixed muscle protein synthesis and breakdown after resistance exercise in humans. Am J Physiol 1997, 273:E99-E107.

25. Tipton KD, Ferrando AA, Phillips SM, Doyle D Jr, Wolfe RR: Postexercise net protein synthesis in human muscle from orally administered amino acids. Am J Physiol 1999, 276:E628-E634.

26. Dreyer HC, Drummond MJ, Pennings B, Fujita S, Glynn EL, Chinkes DL, Dhanani S, Volpi E, Rasmussen BB: Leucine-enriched essential amino acid and carbohydrate ingestion following resistance exercise enhances mTOR signaling and protein synthesis in human muscle. Am J Physiol Endocrinol Metab 2008, 294:E392-E400.

27. Burd NA, West DW, Moore DR, Atherton PJ, Staples AW, Prior T, Tang JE, Rennie MJ, Baker SK, Phillips SM: Enhanced amino acid sensitivity of myofibrillar protein synthesis persists for up to $24 \mathrm{~h}$ after resistance exercise in young men. J Nutr 2011, 141:568-573.

28. Burd NA, West DW, Staples AW, Atherton PJ, Baker JM, Moore DR, Holwerda AM, Parise G, Rennie MJ, Baker SK, Phillips SM: Low-load high volume resistance exercise stimulates muscle protein synthesis more than highload low volume resistance exercise in young men. PLoS One 2010, 5: e12033.

29. Beelen M, Tieland M, Gijsen AP, Vandereyt $H$, Kies AK, Kuipers $H$, Saris WH, Koopman R, van Loon LJ: Coingestion of carbohydrate and protein hydrolysate stimulates muscle protein synthesis during exercise in young men, with no further increase during subsequent overnight recovery. J Nutr 2008, 138:2198-2204

30. Groen BB, Res PT, Pennings B, Hertle E, Senden JM, Saris WH, van Loon L: Intragastric protein administration stimulates overnight muscle protein synthesis in elderly men. Endocrinology and metabolism: American journal of physiology; 2011.

31. Res PT, Groen B, Pennings B, Beelen M, Wallis GA, Gijsen AP, Senden JM, van Loon LJ: Protein Ingestion Prior To Sleep Improves Post-Exercise Overnight Recovery. Medicine and science in sports and exercise 2012, 44 (4):692-700.

32. Kimball SR, Jefferson LS: Control of translation initiation through integration of signals generated by hormones, nutrients, and exercise. $J$ Biol Chem 2010, 285:29027-29032.

33. Dickinson JM, Fry CS, Drummond MJ, Gundermann DM, Walker DK, Glynn EL, Timmerman KL, Dhanani S, Volpi E, Rasmussen BB: Mammalian target of rapamycin complex 1 activation is required for the stimulation of human skeletal muscle protein synthesis by essential amino acids. J Nutr 2011, 141:856-862.

34. Drummond MJ, Fry CS, Glynn EL, Dreyer HC, Dhanani S, Timmerman KL, Volpi E, Rasmussen BB: Rapamycin administration in humans blocks the contraction-induced increase in skeletal muscle protein synthesis. $J$ Physiol 2009, 587:1535-1546.

35. Karlsson HK, Nilsson PA, Nilsson J, Chibalin AV, Zierath JR, Blomstrand E: Branched-chain amino acids increase p70S6k phosphorylation in human skeletal muscle after resistance exercise. Am J Physiol Endocrinol Metab 2004, 287:E1-E7.

36. Koopman R, Wagenmakers AJ, Manders RJ, Zorenc AH, Senden JM, Gorselink M, Keizer HA, van Loon LJ: Combined ingestion of protein and free leucine with carbohydrate increases postexercise muscle protein synthesis in vivo in male subjects. Am J Physiol Endocrinol Metab 2005, 288:E645-E653.

37. Moore DR, Atherton PJ, Rennie MJ, Tarnopolsky MA, Phillips SM: Resistance exercise enhances $\mathrm{mTOR}$ and MAPK signalling in human muscle over that seen at rest after bolus protein ingestion. Acta Physiol (Oxf) 2011, 201:365-372.
38. Greenhaff PL, Karagounis LG, Peirce N, Simpson EJ, Hazell M, Layfield R, Wackerhage H, Smith K, Atherton P, Selby A, Rennie MJ: Disassociation between the effects of amino acids and insulin on signaling, ubiquitin ligases, and protein turnover in human muscle. Am J Physiol Endocrinol Metab 2008, 295:E595-E604.

39. Findlay GM, Yan L, Procter J, Mieulet V, Lamb RF: A MAP4 kinase related to Ste20 is a nutrient-sensitive regulator of mTOR signalling. Biochem $J$ 2007, 403:13-20.

40. Nobukuni T, Joaquin M, Roccio M, Dann SG, Kim SY, Gulati P, Byfield MP, Backer JM, Natt F, Bos JL, et al: Amino acids mediate mTOR/raptor signaling through activation of class 3 phosphatidylinositol $3 \mathrm{OH}$-kinase. Proc Natl Acad Sci USA 2005, 102:14238-14243.

41. Byfield MP, Murray JT, Backer JM: hVps34 is a nutrient-regulated lipid kinase required for activation of p70 S6 kinase. J Biol Chem 2005, 280:33076-33082.

42. Sancak Y, Peterson TR, Shaul YD, Lindquist RA, Thoreen CC, Bar-Peled L, Sabatini DM: The Rag GTPases bind raptor and mediate amino acid signaling to mTORC1. Science 2008, 320:1496-1501.

43. Drummond MJ, Glynn EL, Fry CS, Timmerman KL, Volpi E, Rasmussen BB: An increase in essential amino acid availability upregulates amino acid transporter expression in human skeletal muscle. Am J Physiol Endocrinol Metab 2010, 298:E1011-E1018.

44. Drummond MJ, Fry CS, Glynn EL, Timmerman KL, Dickinson JM, Walker DK, Gundermann DM, Volpi E, Rasmussen BB: Skeletal muscle amino acid transporter expression is increased in young and older adults following resistance exercise. J Appl Physiol 2011, 111:135-142.

45. Hundal HS, Taylor PM: Amino acid transceptors: gate keepers of nutrient exchange and regulators of nutrient signaling. Am J Physiol Endocrinol Metab 2009, 296:E603-E613.

46. Burd NA, Holwerda AM, Selby KC, West DW, Staples AW, Cain NE, Cashaback JG, Potvin JR, Baker SK, Phillips SM: Resistance exercise volume affects myofibrillar protein synthesis and anabolic signalling molecule phosphorylation in young men. J Physiol 2010, 588:3119-3130.

47. Reitelseder S, Agergaard J, Doessing S, Helmark IC, Lund P, Kristensen NB, Frystyk J, Flyvbjerg A, Schjerling P, van Hall G, et al: Whey and casein labeled with L-[1-13 C]leucine and muscle protein synthesis: effect of resistance exercise and protein ingestion. Am J Physiol Endocrinol Metab 2011, 300:E231-E242.

48. Symons TB, Sheffield-Moore M, Mamerow MM, Wolfe RR, Paddon-Jones D The anabolic response to resistance exercise and a protein-rich meal is not diminished by age. J Nutr Health Aging 2011, 15:376-381.

49. Symons TB, Sheffield-Moore M, Wolfe RR, Paddon-Jones D: A moderate serving of high-quality protein maximally stimulates skeletal muscle protein synthesis in young and elderly subjects. J Am Diet Assoc 2009, 109:1582-1586.

50. Phillips SM, Tang JE, Moore DR: The role of milk- and soy-based protein in support of muscle protein synthesis and muscle protein accretion in young and elderly persons. J Am Coll Nutr 2009, 28:343-354.

51. Boirie $Y$, Dangin M, Gachon P, Vasson MP, Maubois $J$, Beaufrere B: Slow and fast dietary proteins differently modulate postprandial protein accretion. Proc Natl Acad Sci USA 1997, 94:14930-14935.

52. Burd NA, Yang Y, Moore DR, Tang JE, Tarnopolsky MA, Phillips SM: Greater stimulation of myofibrillar protein synthesis with ingestion of whey protein isolate $v$. micellar casein at rest and after resistance exercise in elderly men. Br J Nutr 2012, :1-5 [Epub ahead of print].

53. West DW, Burd NA, Coffey VG, Baker SK, Burke LM, Hawley JA, Moore DR, Stellingwerff T, Phillips SM: Rapid aminoacidemia enhances myofibrillar protein synthesis and anabolic intramuscular signaling responses after resistance exercise. Am J Clin Nutr 2011, 94:795-803.

54. Dangin M, Boirie Y, Garcia-Rodenas C, Gachon P, Fauquant J, Callier P, Ballevre O, Beaufrere $B$ : The digestion rate of protein is an independent regulating factor of postprandial protein retention. Am J Physiol Endocrinol Metab 2001, 280:E340-E348.

55. Dangin $M$, Boirie $Y$, Guillet $C$, Beaufrere B: Influence of the protein digestion rate on protein turnover in young and elderly subjects. $J$ Nutr 2002, 132:3228S-3233S.

56. Nair KS, Halliday D, Griggs RC: Leucine incorporation into mixed skeletal muscle protein in humans. Am J Physiol 1988, 254:E208-E213.

57. Nakshabendi IM, Obeidat W, Russell RI, Downie S, Smith K, Rennie MJ: Gut mucosal protein synthesis measured using intravenous and intragastric delivery of stable tracer amino acids. Am J Physiol 1995, 269:E996-E999. 
58. Carraro F, Hartl WH, Stuart CA, Layman DK, Jahoor F, Wolfe RR: Whole body and plasma protein synthesis in exercise and recovery in human subjects. Am J Physiol 1990, 258:E821-E831.

59. Conley TB, Apolzan JW, Leidy HJ, Greaves KA, Lim E, Campbell WW: Effect of food form on postprandial plasma amino acid concentrations in older adults. Br J Nutr 2011, 106:203-207.

60. Bohe J, Low A, Wolfe RR, Rennie MJ: Human muscle protein synthesis is modulated by extracellular, not intramuscular amino acid availability: a dose-response study. J Physiol 2003, 552:315-324.

61. Norton LE, Layman DK, Bunpo P, Anthony TG, Brana DV, Garlick PJ: The leucine content of a complete meal directs peak activation but not duration of skeletal muscle protein synthesis and mammalian target of rapamycin signaling in rats. J Nutr 2009, 139:1103-1109.

62. Rennie MJ, Bohe J, Smith K, Wackerhage H, Greenhaff P: Branched-chain amino acids as fuels and anabolic signals in human muscle. J Nutr 2006, 136:264S-268S.

63. Tipton KD, Gurkin BE, Matin S, Wolfe RR: Nonessential amino acids are not necessary to stimulate net muscle protein synthesis in healthy volunteers. J Nutr Biochem 1999, 10:89-95.

64. Volpi E, Kobayashi H, Sheffield-Moore M, Mittendorfer B, Wolfe RR: Essential amino acids are primarily responsible for the amino acid stimulation of muscle protein anabolism in healthy elderly adults. Am J Clin Nutr 2003, 78:250-258.

65. Smith K, Reynolds N, Downie S, Patel A, Rennie MJ: Effects of flooding amino acids on incorporation of labeled amino acids into human muscle protein. Am J Physiol 1998, 275:E73-E78.

66. Anthony JC, Yoshizawa F, Anthony TG, Vary TC, Jefferson LS, Kimball SR: Leucine stimulates translation initiation in skeletal muscle of postabsorptive rats via a rapamycin-sensitive pathway. J Nutr 2000, 130:2413-2419.

67. Crozier SJ, Kimball SR, Emmert SW, Anthony JC, Jefferson LS: Oral leucine administration stimulates protein synthesis in rat skeletal muscle. $J$ Nutr 2005, 135:376-382.

68. Escobar J, Frank JW, Suryawan A, Nguyen HV, Kimball SR, Jefferson LS, Davis TA: Regulation of cardiac and skeletal muscle protein synthesis by individual branched-chain amino acids in neonatal pigs. Am J Physiol Endocrinol Metab 2006, 290:E612-E621.

69. Atherton PJ, Smith K, Etheridge T, Rankin D, Rennie MJ: Distinct anabolic signalling responses to amino acids in C2C12 skeletal muscle cells. Amino Acids 2010, 38:1533-1539.

70. Katsanos CS, Kobayashi H, Sheffield-Moore M, Aarsland A, Wolfe RR: A high proportion of leucine is required for optimal stimulation of the rate of muscle protein synthesis by essential amino acids in the elderly. Am J Physiol Endocrinol Metab 2006, 291:E381-E387.

71. Rieu I, Balage M, Sornet C, Giraudet C, Pujos E, Grizard J, Mosoni L, Dardevet $D$ : Leucine supplementation improves muscle protein synthesis in elderly men independently of hyperaminoacidaemia. J Physiol 2006, 575:305-315.

72. Doherty TJ: Invited review: Aging and sarcopenia. J App/ Physio/ 2003, 95:1717-1727.

73. Volpi E, Mittendorfer B, Rasmussen BB, Wolfe RR: The response of muscle protein anabolism to combined hyperaminoacidemia and glucoseinduced hyperinsulinemia is impaired in the elderly. J Clin Endocrinol Metab 2000, 85:4481-4490.

74. Kumar V, Selby A, Rankin D, Patel R, Atherton P, Hildebrandt W, Williams J, Smith K, Seynnes O, Hiscock N, Rennie MJ: Age-related differences in the dose-response relationship of muscle protein synthesis to resistance exercise in young and old men. J Physiol 2009, 587:211-217.

75. Wilkes EA, Selby AL, Atherton PJ, Patel R, Rankin D, Smith K, Rennie MJ: Blunting of insulin inhibition of proteolysis in legs of older subjects may contribute to age-related sarcopenia. Am J Clin Nutr 2009, 90:1343-1350.

76. Yang Y, Breen L, Burd NA, Hector AJ, Churchward-Venne TA, Josse AR, Tarnopolsky MA, Phillips SM: Resistance exercise enhances myofibrillar protein synthesis with graded intakes of whey protein in older men. $\mathrm{Br} J$ Nutr 2012,:1-9 [Epub ahead of print].

77. Verhoeven S, Vanschoonbeek K, Verdijk LB, Koopman R, Wodzig WK Dendale $\mathrm{P}$, van Loon LJ: Long-term leucine supplementation does not increase muscle mass or strength in healthy elderly men. Am J Clin Nutr 2009, 89:1468-1475.

78. Escobar J, Frank JW, Suryawan A, Nguyen HV, Kimball SR, Jefferson LS, Davis TA: Physiological rise in plasma leucine stimulates muscle protein synthesis in neonatal pigs by enhancing translation initiation factor activation. Am J Physiol Endocrinol Metab 2005, 288:E914-E921.

79. Escobar J, Frank JW, Suryawan A, Nguyen HV, Davis TA: Amino acid availability and age affect the leucine stimulation of protein synthesis and elF4F formation in muscle. Am J Physiol Endocrinol Metab 2007, 293: E1615-E1621.

80. Smith Gl, Atherton P, Reeds DN, Mohammed BS, Rankin D, Rennie MJ, Mittendorfer B: Omega-3 polyunsaturated fatty acids augment the muscle protein anabolic response to hyperinsulinaemiahyperaminoacidaemia in healthy young and middle-aged men and women. Clin Sci (Lond) 2011, 121:267-278.

81. Smith Gl, Atherton P, Reeds DN, Mohammed BS, Rankin D, Rennie MJ, Mittendorfer B: Dietary omega-3 fatty acid supplementation increases the rate of muscle protein synthesis in older adults: a randomized controlled trial. Am J Clin Nutr 2011, 93:402-412.

82. Rodacki CL, Rodacki AL, Pereira G, Naliwaiko K, Coelho I, Pequito D, Fernandes LC: Fish-oil supplementation enhances the effects of strength training in elderly women. Am J Clin Nutr 2012, 95:428-436.

83. Elliot TA, Cree MG, Sanford AP, Wolfe RR, Tipton KD: Milk ingestion stimulates net muscle protein synthesis following resistance exercise. Medicine and science in sports and exercise 2006, 38:667-674.

84. Miller SL, Tipton KD, Chinkes DL, Wolf SE, Wolfe RR: Independent and combined effects of amino acids and glucose after resistance exercise. Medicine and science in sports and exercise 2003, 35:449-455.

85. Gelfand RA, Barrett EJ: Effect of physiologic hyperinsulinemia on skeletal muscle protein synthesis and breakdown in man. J Clin Invest 1987, 80: $1-6$.

86. Biolo G, Williams BD, Fleming RY, Wolfe RR: Insulin action on muscle protein kinetics and amino acid transport during recovery after resistance exercise. Diabetes 1999, 48:949-957.

87. Roy BD, Tarnopolsky MA: Influence of differing macronutrient intakes on muscle glycogen resynthesis after resistance exercise. J App/ Physio/ 1998, 84:890-896.

88. Pascoe DD, Costill DL, Fink WJ, Robergs RA, Zachwieja JJ: Glycogen resynthesis in skeletal muscle following resistive exercise. Medicine and science in sports and exercise 1993, 25:349-354.

89. Hawley JA, Burke LM, Phillips SM, Spriet LL: Nutritional modulation of training-induced skeletal muscle adaptations. J Appl Physiol 2011, $110: 834-845$.

doi:10.1186/1743-7075-9-40

Cite this article as: Churchward-Venne et al:: Nutritional regulation of muscle protein synthesis with resistance exercise: strategies to enhance anabolism. Nutrition \& Metabolism 2012 9:40.

\section{Submit your next manuscript to BioMed Central and take full advantage of:}

- Convenient online submission

- Thorough peer review

- No space constraints or color figure charges

- Immediate publication on acceptance

- Inclusion in PubMed, CAS, Scopus and Google Scholar

- Research which is freely available for redistribution 